\title{
KOMPARASI PENDAPATAN PETANI KOPI ORGANIK DAN KONVENSIONAL (Suatu Kasus di Desa Margamulya, Kecamatan Pangalengan, Kabupaten Bandung, Jawa Barat)
}

\author{
COMPARISON OF INCOME ORGANIC AND CONVENTIONAL COFFEE \\ FARMERS (CASE IN MARGAMULYA VILLAGE, PANGALENGAN REGENCY, \\ BANDUNG REGENCY, WEST JAVA
}

\author{
Rahma Az-Zahra Saroja*, Tuti Karyani \\ Program Studi Agrbisnis Fakultas Pertanian Universitas Padjadjaran, Jl. Raya Jatinangor No. 21 \\ *E-mail: zahrasaroja@gmail.com \\ (Diterima 12-08-2020; Disetujui 07-09-2020)
}

\begin{abstract}
ABSTRAK
Permintaan produk organik semakin meningkat disebabkan oleh adanya perubahan pada pola atau gaya hidup konsumen. Kesadaran tentang bahaya yang ditimbulkan oleh pemakaian bahan kimia sintetis dalam budidaya pertanian menjadikan pertanian organik atau pertanian berkelanjutan menarik perhatian dari konsumen dan produsen kopi organik. Pemerintah mendukung adanya tren produk organik dengan membentuk program 1.000 desa pertanian organik. Penelitian ini bertujuan untuk menganalisis perbedaan pendapatan petani kopi organik dan konvensional. Penelitan ini dilakukan di Desa Margamulya, Kecamatan Pangalengan, Jawa Barat yang dipilih secara sengaja dengan pertimbangan Desa Margamulya sebagai sentra produksi kopi Jawa Barat, dan salah satu desa yang terpilih menjadi salah desa organik dalam program 1.000 desa pertanian organik di Indonesia. Sampel yang digunakan berjumlah 56 responden yang terdiri atas 28 petani organik dan 28 petani konvensional yang diperoleh melalui rumus slovin dan diambil dengan teknik area sampling. Metode yang digunakan adalah metode penelitian kuantitatif komparatif. Data dianalisis dengan analisis perbandingan pendapatan menggunakan Independent Sample T-Test. Hasil analisis menunjukkan bahwa pendapatan petani konvensional lebih tinggi dari petani organik. Hasil produksi petani kopi organik masih rendah karena masih baru menerapkan sistem budidaya organik, petani organik belum mendapatkan harga premium untuk produk kopi organiknya.
\end{abstract}

Kata kunci: Petani Kopi, Organik, Konvensional, Pendapatan

\section{ABSTRACT}

The demand for organic products is increasing because of changes in consumer patterns or lifestyles. Awareness of the dangers used synthetic chemicals in agricultural cultivation makes organic farming or sustainable agriculture attract the attention of consumers and producers of organic coffee. The government supports the trend of organic products by forming a program of 1,000 organic farming villages. This study aims to analyze differences in income of organic and conventional coffee farmers. This research was conducted in Margamulya Village, Pangalengan Regency, West Java. Margamulya Village as the center of West Java coffee production and one of the villages chosen as one of the organic villages in the 1000 organic farming village program in Indonesia. The sample used in this study was 56 respondents consisting of 28 organic farmers and 28 conventional farmers obtained through the Slovin formula and taken by area sampling methods. The method used in this research is comparative quantitative research methods. Data analyzed with comparative income analysis using the Independent Sample T-Test. The analysis shows that the income of conventional farmers is higher than organic farmers. The production of organic coffee farmers still lower then conventional farmers because they are still new to applying the organic cultivation system. Organic farmers have not received a premium price for their organic coffee products.

Keywords: Coffee Farmer, Organic, Conventional, Income 


\section{PENDAHULUAN}

Kopi merupakan salah satu komoditas hasil perkebunan yang memiliki peran penting dalam kegiatan perekonomian di Indonesia. Kopi juga salah satu komoditas ekspor Indonesia yang cukup penting sebagai penghasil devisa negara. Indonesia memiliki potensi pengembangan usaha kopi yang besar. Pada tahun 2015 luas perkebunan kopi Indonesia mencapai 1.227.787 ha dengan total produksi 637.539 ton. Perkebunan kopi Indonesia didominasi oleh perkebunan rakyat $(95,60 \%)$ dan melibatkan petani secara langsung sebanyak 1,1 juta KK (BPS, 2016). Volume ekspor Indonesia dari tahun 2011 hingga 2015 cenderung mengalami peningkatan meskipun terjadi penurunan volume eskpor pada tahun 2014, tetapi pada tahun 2015 kembali mengalami peningkatan volume eskpor. Selain peluang ekspor yang masih terbuka, pasar kopi di dalam negeri masih cukup besar (BPS, 2017).

Saat ini permintaan akan produk organik semakin meningkat. Hal ini disebabkan oleh adanya perubahan pada pola atau gaya hidup konsumen. Kesadaran tentang bahaya yang ditimbulkan oleh pemakaian bahan kimia sintesis dalam budidaya pertanian menjadikan pertanian organik atau pertanian berkelanjutan menarik perhatian dari produsen maunpun konsumen. Konsumen yang menyadari akan dampak bahan kimia sintesis bagi kesehatan akan memilih bahan pangan yang aman bagi kesehatan dan ramah lingkungan sehingga mendorong permintaan produk organik (Fatmalasari, 2016). Standar lingkungan, sosial, dan keamanan pangan dalam proses budidaya merupakan bagian dari standar mutu dalam perdagangan produk organik (Mayrowani, 2012).

Bagi negara-negara berkembang, khususnya Indonesia, pangan organik masih menjadi hal yang baru dan mulai populer di awal tahun 2010an. Permintaan pangan organik meningkat di seluruh dunia, dan jika Indonesia bisa memenuhi kebutuhan ini serta bisa meningkatkan ekspor produk organik, akan meningkatkan daya saing usaha pertanian (agribisnis) di Indonesia, dan dapat meningkatkan devisa dan pendapatan rumah tangga tani. Produk pertanian organik utama yang dihasilkan Indonesia adalah padi, sayuran, buahbuahan, kopi, coklat, jambu mete, herbal, minyak kelapa, rempah-rempah, dan madu Damardjati (2005) dalam Mayrowani (2012). Keberlanjutan pertanian organik tidak dapat dipisahkan 
dengan dimensi ekonomi, selain dimensi lingkungan, dan dimensi sosial. Pertanian organik tidak hanya sebatas meniadakan penggunaan input sintetis, tetapi juga pemanfaatan sumber-sumber daya alam secara berkelanjutan, produksi makanan sehat, dan menghemat energi. Aspek ekonomi dapat berkelanjutan bila produksi pertanian mampu mencukupi kebutuhan dan memberikan pendapatan yang cukup bagi petani (Mayrowani, 2012).

Perkembangan produksi kopi organik dari tahun ke tahun semakin meningkat, sedangkan kopi konvensional mengalami penurunan jumlah produksi. Dari tahun 2008-2016 produksi kopi organik meningkat sebesar 24\%, sedangkan produksi kopi organik global menurun sebesar 8\% (Voora et al, 2019). Total produksi kopi di dunia pada tahun 2016, kopi organik yang sesuai dengan aturan organik menyumbang setidaknya $34 \%$ dari total produksi kopi, produk kopi semi organik sebesar $21,4 \%$ dan kopi konvensional sebesar $44 \%$ dari total produksi kopi. Voora et al (2019) menyatakan bahwa pada tahun 2016 setidaknya 3 juta ton metrik permintaan kopi organik bernilai 7,2 miliar dolar. Nilai ini berasal dari rata-rata harga produsen per negara. Sebagaimana dilaporkan oleh FAO saat itu 70\% kopi organik berasal dari Amerika Latin (Brazil, Kolombia, dan Peru) dan beberapa volume kopi penting dari Asia (Vietnam dan Indonesia), dan Afrika (Ethiopia, Tanzania, dan Uganda).

Jika dilihat dari segi permintaan, terdapat 10 perusahaan Coffee Roaster terbesar yang membeli total 3,31 juta ton metrik kopi pada tahun 2016, terhitung $35 \%$ dari total sumber kopi global. Dari total ini sebanyak 1,14 juta ton metrik merupakan kopi organik. Hal ini terjadi karena beberapa perusahaan berinisiatif untuk menerapkan konsep keberlanjutan pada produksi kopi. Beberapa perusahaan Coffee Roaster di dunia membentuk program seperti Starbucks CAFÉ Practices dan Nestle's Nepresso AAA Programs. Terdapat tanda-tanda ekspansi penerapan kopi organik yang berpotensi menjanjikan di antara negara-negara yang sudah berproduksi sebagai bagian penting dari produsen kopi dunia dan sudah menerapkan sistem budidaya kopi organik. Negara-negara penghasil kopi teratas seperti Brazil, Vietnam, Indonesia, Ethiopia, dan Kolombia menawarkan prospek yang bagus untuk meningkatkan produksi kopi yang berkelanjutan. Inisiatif perusahaan yang mensyaratkan sistem berkelanjutan pada produk 
kopinya mendorong sektor pertanian kopi ke arah yang berpotensi menjadi salah satu komoditas pertama yang mecapai kepatuhan tinggi secara signifikan dengan inisiatif keberlanjutan (organik). Dari sepuluh perusahaan terbesar yang menjadi konsumen kopi semuanya telah membeli produk kopi organik dan konvensional, sedangkan beberapa perusahaan seperti Nestle, Starbucks, dan Keurig Green Mountain berkomitmen untuk beralih dalam menyediakan kopi organik hal ini membuktikan semakin tinggi peluang dan potensi bagi petani kopi organik untuk meproduksi produk kopi organik karena permintaan kopi organik dari tahun ke tahun meningkat (Voora et al, 2019).

Pemerintah Jawa Barat berupaya mengembangkan kopi khas Jawa Barat dari jenis kopi arabika yang telah mendapatkan indikasi geografis pada tahun 2013 dengan nama Java Preanger Kopi. Perkebunan kopi arabika Java Preanger tersebar di beberapa titik tempat salah satunya adalah Gunung Tilu. Kopi ditanam oleh petani khususnya masyarakat petani sekitar hutan yang diizinkan oleh Perhutani dalam sistem Pengelolaan Hutan Bersama Masyarakat (PHBM) (BPS, 2016). Direktorat Jenderal Perkebunan Kementerian
Pertanian Republik Indonesia mendukung kebutuhan pasar kopi, salah satunya dengan mewujudkan Program Pengembangan 1.000 Desa Pertanian Organik. Program Pengembangan Desa Pertanian Organik memiliki tujuan di antaranya menumbuhkan petani mandiri dengan menggunakan input produksi secara organik dalam kegiatan budidaya, memperbaiki lahan kritis, meningkatkan kualitas hasil produksi, serta meningkatkan kesejahteraan petani. Dari 14 kelompok tani yang tersebar di beberapa kabupaten di Provinsi Jawa Barat, Kelompok Tani Kopi Margamulya, Desa Margamulya, Kecamatan Pangalengan Kabupaten Bandung terpilih menjadi salah satu kelompok tani yang diikutsertakan dalam Program Pengembangan Desa Organik.

Harga yang diberikan di Desa Margamulya untuk hasil usahatani kopi organik jauh lebih tinggi dibandingkan hasil usahatani kopi konvensional. harga ceri kopi organik dihargai lebih tinggi sekitar 15\% dari harga per kilogram ceri kopi konvensional. Berbeda dengan harga ceri, produk hasil olahan kopi organik berupa greenbean dapat lebih tinggi 50\% dari harga greenbean kopi konvensional. Kenyataanya kegiatan usahatani kopi organik masih sulit untuk diterapkan. 
Tidak semua petani dapat memenuhi syarat untuk mendapatkan sertifikasi kopi organik. Di Desa Margamulya hanya terdapat 28 petani yang tercatat sebagai anggota kelompok tani kopi organik Margamulya, sisanya merupakan petani kopi konvensional yang tergabung dalam kelompok tani kopi Margamulya. Selain itu, berdasarkan pernyataan dari ketua kelompok tani kopi Margamulya, pasar untuk produk kopi organik masih belum jelas serta tingginya biaya yang diperlukan untuk membayar sertifikasi membuat petani masih ragu untuk melakukan usahatani kopi organik di Desa Margamulya. Meskipun saat ini biaya sertifikasi masih dibantu oleh Dinas Perkebunan Jawa Barat. Hal ini menarik untuk dikaji mengapa petani ada yang melakukan sistem budidaya organik dan konvensional, bagaimana perbandingan pendapatan kopi organik dan konvensional.

\section{METODE PENELITIAN}

Desain penelitian ini menggunakan penelitian kuantitatif komparatif. Penelitian kuantitatif merupakan metode penelitian yang berlandaskan pada filsafat positivisme, digunakan untuk meneliti pada populasi atau sampel tertentu, pengumpulan data menggunakan instrumen penelitian, analisis data bersifat kuantitatif, dengan tujuan untuk menggambarkan dan menguji hipotesis yang telah ditetapkan (Sugiyono, 2018). Sementara penelitian komparatif menurut Sugiyono (2018) yaitu penelitian yang membandingkan keberadaan satu variabel atau lebih pada dua atau sampel yang berbeda, atau pada waktu yang berbeda. Pengambilan sampel pada penelitian ini menggunakan teknik pengambilan sampel probability sampling. Teknik pengambilan sampel mengunakan area sampling yang merupakan bagian dari probability sampling pengambilan sampel berdasarkan daerah populasi yang telah ditetapkan (Sugiyono, 2018).

Analisis data yang digunakan penelitian ini untuk digunakan mengintepretasikan data yang telah dikumpulkan kemudian dijadikan dasar pengambilan keputusan (Karyani, 2020):

1. Analisis Pendapatan

Analisis pendapatan digunakan untuk mencari besaran tingkat pendapatan yang diperoleh petani kopi organik maupun konvensional. Pendapatan merupakan selisih antara penerimaan dengan semua biaya yang dikeluarkan selama melakukan kegiatan usaha (Soekartawi, 1995). Berikut ini 
adalah rumus untuk mencari pendapatan usahatani:

$$
\mathrm{Pd}=\mathrm{TR}-\mathrm{TC}
$$

Kerterangan:

$\mathrm{Pd}=$ Pendapatan Usahatani $(\mathrm{Rp})$

$\mathrm{TR}=$ Total Penerimaan $(\mathrm{Rp})$

$\mathrm{TC}=$ Total Biaya $(\mathrm{Rp})$

2. Uji Beda

Independent sample $t$ test merupakan uji komparatif atau uji beda untuk membandingkan dan mengetahui perbedaan antara dua kelompok bebas yang berskala data interval atau rasio. Dua kelompok bebas yang diuji merupakan dua kelompok yang tidak berpasangan. Sumber data diperolah dari dua subjek yang berbeda.

Sebelum melakukan uji $t$ test (Independent Sample t-Test) dilakukan uji kesamaan varian dengan $F$ test (Levene's Test) terlebih dahulu. Jika hasil variannya homogen maka digunakan Equal Variance Assumed, namun jika variannya berbeda atau heterogen maka menggunakan Equal Variance Not Assumed (Priyanto, 2008). Data diolah menggunakan bantuan alat hitung Statistical Package for the Social Science (SPSS).

Objek yang diteliti yaitu pendapatan petani organik dan pendapatan petani konvensional di Desa Margamulya
Kecamatan Pangalengan. Dalam pengolahan data pada SPSS menggunakan fungsi Analyze-Compare Means-Independent Samples $T$ test. Menurut Sugiyono (2018) Independent Sample t-Test dapat ditulis dengan rumus:

$\mathrm{T}$ hitung $=\frac{X_{1}-X_{2}}{\sqrt{\frac{\left(n_{1}-1\right) S_{1}{ }^{2}+\left(n_{2}-1\right) S_{2}{ }^{2}}{n_{1}+n_{2}-2}}\left(\frac{1}{n_{1}}+\frac{1}{n_{2}}\right)}$

Keterangan:

$\mathrm{X}_{1}$ : Rata-rata Pendapatan Petani Kopi Organik

$\mathrm{X}_{2}$ : Rata-rata Pendapatan Petani Kopi Konvensional

$\mathrm{n}_{1}$ : Banyaknya Sampel Petani Organik

$\mathrm{n}_{2} \quad$ Banyaknya Sampel Petani Konvensional

$\mathrm{S}_{1}$ : Standar Deviasi Pendapatan Petani Kopi Organik

$\mathrm{S}_{2}$ : Standar Deviasi Pendapatan Petani Kopi Konvensional

Dasar pengambilan keputusan dalam uji Independent Sample t-Test sebagai berikut:

- Terima $\mathrm{H}_{0}$ dan tolak $\mathrm{H}_{\mathrm{a}}$, jika nilai Sig. (2-tailed) $>\alpha$ berarti tidak ada perbedaan pendapatan antara pendapatan petani kopi organik dan pendapatan petani kopi konvensional.

- Terima $\mathrm{H}_{\mathrm{a}}$ dan tolak $\mathrm{H}_{0}$, jika nilai Sig. (2-tailed) $<\alpha$ berarti terdapat 
perbedaan pendapatan antara pendapatan petani kopi organik dan pendapatan petani kopi konvensional.

\section{HASIL DAN PEMBAHASAN}

Desa Margamulya merupakan desa yang memiliki lahan budidaya kopi, Desa Margamulya pertama di Kecamatan Pangalengan yang terpilih menjadi salah satu dari 1.000 desa petanian organik di Indonesia. Desa Margamulya terdapat kelompok tani kopi petani organik dan konvensional. Namun, tidak semua anggota kelompok tani dapat menjadi anggota kelompok tani kopi organik di Desa Margamulya karena keterbatasan kuota yang diberikan melalui program 1000 desa pertanian organik.

\section{Analisis Pendapatan}

Untuk menghitung pendapatan dalam usahatani dapat dilakukan dengan tiga macam pendekatan, yaitu pendekatan nominal (Nominal Approach), pendekatan nilai yang akan datang
(Future Value Approach), dan pendekatan nilai sekarang (Present Value Approach). Pada penelitian ini pendekatan yang digunakan adalah pendekatan nominal, pendekatan tanpa memperhitungkan nilai uang menurut waktu (time value of money). Tetapi menggunakan harga yang berlaku, sehingga menghitung langsung jumlah pengeluaran dan jumlah penerimaan dalam suatu periode proses produksi pada waktu eksisting (Suratiyah, 2015).

$$
\text { Menurut Soekartawi (1995), }
$$
pendapatann usahatani merupakan selisih antara penerimaan dan semua biaya, dinyatakan dengan rumus $\mathrm{Pd}=\mathrm{TR}-\mathrm{RC}$, dimana Pd adalah pendapatan usahatani kopi, TR merupakan Total Revenue atau total penerimaan, dan TC merupakan Total Cost atau total pengeluaran. Hasil analisis pendapatan pada petani kopi organik dan konvensional tersaji pada Tabel 1.

Tabel 1. Pendapatan Rata-rata Budidaya Kopi Organik dan Konvensional

\begin{tabular}{llll}
\hline & $\begin{array}{l}\text { Penerimaan } \\
\text { (Rp/ Tahun) }\end{array}$ & $\begin{array}{l}\text { Pengeluaran } \\
\text { (Rp/ Tahun) }\end{array}$ & $\begin{array}{l}\text { Pendapatan } \\
\text { (Rp/ Tahun) }\end{array}$ \\
\hline \multicolumn{3}{c}{ Per Petani } \\
Kopi Organik(0,74 Ha) & 18.190 .714 & 8.782 .940 & 9.407 .774 \\
Kopi Konvensional (0,39 Ha) & 15.127 .143 & 6.696 .643 & 8.430 .500 \\
\hline \multicolumn{4}{c}{ Per Hektar } \\
Kopi Organik & 31.808 .411 & $14.373 .855,2$ & 17.434 .556 \\
Kopi Konvensional & 46.506 .470 & $19.602 .547,5$ & 26.903 .922 \\
\hline
\end{tabular}

Berdasarkan Tabel 1, pendapatan rata-rata per luas lahan petani kopi organik lebih tinggi dibandingkan pendapatan rata-rata per luas lahan petani kopi konvensional. Hal ini disebabkan karena petani kopi secara organik 
memiliki rata-rata luas lahan yang lebih luas daripada petani kopi konvensional. Namun, apabila dilihat dari segi luasan per hektar, pendapatan rata-rata per hektar petani kopi organik lebih rendah daripada pendapatan rata-rata per hektar petani kopi konvensional. Pendapatan rata-rata petani kopi organik lebih rendah diakibatkan karena pengeluaran petani organik yang lebih besar dibandingkan pengeluaran petani kopi konvensional. Rata-rata pengeluaran per hektar petani kopi organik sebesar $45,1 \%$ dari total penerimaan, sedangkan rata-rata pengeluaran per hektar petani konvensional lebih rendah yaitu 42,1\% dari total penerimaan.

Perbedaan pengeluaran biaya yang lebih tinggi pada petani kopi organik disebabkan oleh tingginya pengeluaran biaya tenaga kerja. Petani kopi organik selain harus menggunakan pupuk organik dan bahan organik seperti pestisida organik untuk mengendalikan hama dan penyakit pada tanaman kopinya, petani kopi organik juga melakukan metode mekanis pada pengendalian gulma, hal ini menyebabkan petani kopi organik harus mengeluarkan biaya tenaga kerja yang lebih besar daripada petani konvensional. Petani konvensional dapat mengendalikan hama dan penyakit pada tanaman dengan pemberian pestisida atau obat berbahan kimia tanpa harus melakukan pengendalian hama menggunakan metode mekanis. Hasil penelitian didukung oleh penelitian Saragih (2013) dalam Fatmalasari (2016) yang menunjukkan bahwa rata-rata pendapatan petani kopi organik di Kabupaten Simalungun lebih rendah dari petani konvensional. Pendapatan petani kopi organik sebesar Rp 26.210.000/ha dan untuk petani kopi konvensional sebesar Rp48.020.00/ha.

\section{Analisis Perbandingan Pendapatan}

Hasil dari olah data uji beda tidak berpasangan pendapatan petani menggunakan alat bantu hitung SPSS menunjukkan hasil untuk perbedaan pendapatan petani kopi organik dan konvensional tersaji pada Tabel 2. 
Tabel 2. Hasil Uji t perbedaan pendapatan antara petani kopi organik dan konvensional

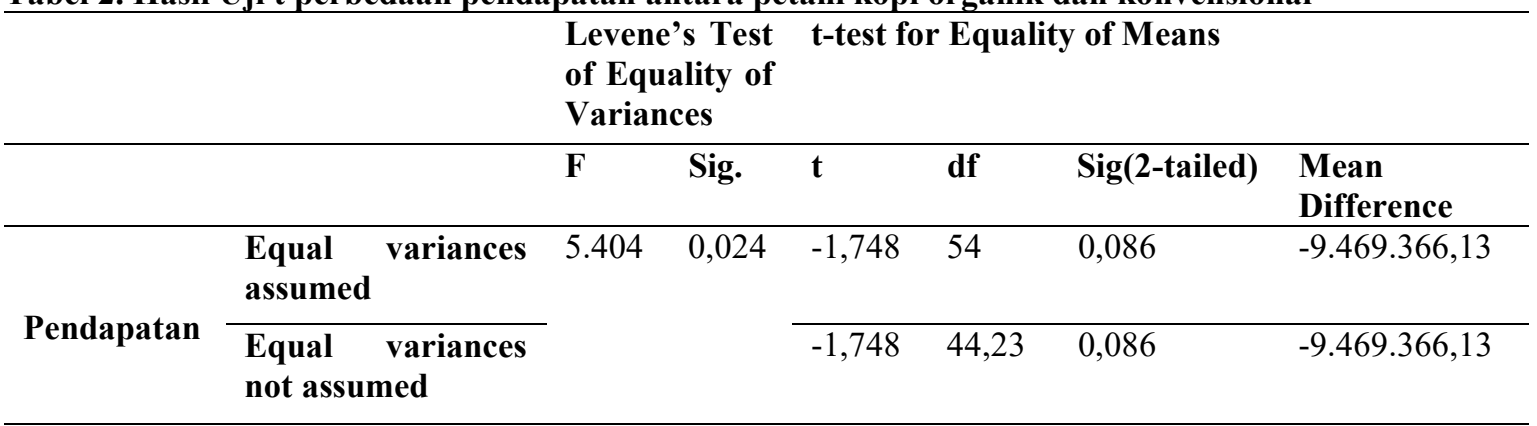

Berdasarkan Tabel 2, pendapatan petani organik dan petani konvensional memiliki nilai $\mathrm{F}=5,404$ atau $\mathrm{p}=0,024$ adalah heterogen $(p<0,05)$. Data tidak homogen berarti terdapat varians pada data pendapatan petani kopi organk dan konvensional. Karena datanya tidak homogen yang perlu dilihat yaitu pada baris equal variance not assumed (varian populasi tidak identik) nilai t hitung $=$ -
1,748 (sig < 0,05) dan nilai Sig (2-Tailed) $0,086>\alpha$ dengan nilai signifikansi $(\alpha)$ sebesar 0,05 maka sebagaimana pengambilan keputusan dalam Uji Independent $T$ Test dapat disimpulkan bahwa terima $\mathrm{H}_{0}$ dan tolak $\mathrm{H}_{1}$. Dengan demikian tidak ada perbedaan yang signifikan antara pendapatan petani kopi organik dan konvensional.

Tabel 3. Group Statistics Perbandingan pendapatan petani kopi organik dan konvensional

\begin{tabular}{llllll}
\hline & $\begin{array}{l}\text { Sistem } \\
\text { Budidaya }\end{array}$ & N & Mean & Std. Deviation & $\begin{array}{l}\text { Std. } \\
\text { Mean }\end{array}$ \\
\hline \multirow{2}{*}{ Pendapatan } & Organik & 28 & 17434555.91 & 14757933.67 & 2788987.31 \\
& Konvensional & 28 & 26903922.05 & 24577380.26 & 4644688.29 \\
\hline
\end{tabular}

Dikatakan tidak terdapat perbedaan yang signifikan, jika dilihat hasil perhitungan pada Tabel 3 bahwa rata-rata pendapatan petani kopi konvensional lebih tinggi dari pendapatan petani organik $(R p \quad 26.903 .922>R p$ 17.434.555). Pendapatan petani kopi organik dan konvensional tetap memiliki selisih pendapatan, hanya saya selisihnya tidak banyak sehingga perbedaan pendapatan yang diuji tidak signifikan. Dapat dilihat pada Tabel 3 mean difference yaitu sebesar -9469366,1369 atau pendapatan rata-rata petani kopi konvensional lebih tinggi senilai $\mathrm{Rp}$ 9.469.366,1369 dibandingkan pendapatan petani kopi organik. Berbeda dengan hasil penelitian Fatmalasari (2016) yang menunjukkan bahwa rata-rata pendapatan petani kopi organik di Kabupaten 
Lampung Barat lebih tinggi dari petani konvensional, pendapatan petani kopi organik sebesar Rp 10.920.999,64/ha dan untuk petani kopi konvensional sebesar Rp 8.962.978,43/ha.

Harga premium (premium price) juga belum dirasakan oleh seluruh anggota petani organik. Petani yang menjual ke Koperasi Produsen Kopi Margamulya hanya memperoleh harga lebih tinggi sebesar Rp 500 - Rp 2000/kg dari harga yang berlaku di daerah penelitian. Hasil penelitian ini didukung oleh penelitian yang dilakukan Fatmalasari (2016) yang menunjukkan bahwa selisih harga ceri yang diperoleh petani kopi organik lebih tinggi sebesar Rp 2.000/kg dari harga ceri kopi konvensional. Selisih harga tersebut merupakan premium fee bagi petani atas usahanya melakukan usahatani kopi secara organik.

Perbedaan harga yang diberikan oleh kelompok tani tidak terlalu jauh. Hal ini disebabkan karena kelompok tani kopi organik Margamulya belum mendapatkan buyer atau pembeli yang secara konsisen memesan dan memastikan untuk membeli produk organik yang dihasilkan oleh kelompok tani kopi organik Margamulya. Harga yang didapatkan petani masih harga yang hampir sama dengan yang diberikan kepada petani kopi konvensional. Berdasarkan pernyataan yang diberikan oleh pengurus kelompok tani kopi organik Margamulya, harga yang berbeda kepada petani kopi organik merupakan bentuk apresiasi kepada petani kopi yang sudah bersedia mengonversikan sistem usahataninya ke sistem pertanian orgnaik, dan sudah berusaha menjaga produk pertaniannya sesuai dengan ketentuan kopi organik yang telah ditetapkan. Meskipun harga yang diberikan tidak terlalu jauh, tetapi kelompok tani berusaha membedakan harga yang diberikan agar petani lebih termotivasi untuk menerapkan sistem budidaya organik.

Pengurus kelompok tani kopi organik Margamulya saat ini masih mengusahakan untuk mencari buyer atau peminat kopi organik yang dapat menghargai dan memberikan harga yang sesuai dengan kualitas yang dihasilkan yaitu produk organik yang sesuai dengan ketentuan. Menurut Karyani (2018), petani anggota kelompok tani kopi melalui koperasi petani kopi Margamulya pernah melakukan kotrak dengan PT. Taman Delta yang membeli produk semi organik (sertifikasi UTZ) dengan sistem kontrak pembelian jangka panjang, namun saat ini kontrak dengan PT. 
Taman Delta sudah tidak berlaku sehingga pengurus kelompok tani kopi organik Margamulya saat ini masih gencar melakukan promosi dan pengenalan produk kepada konsumen. Berdasarkan pernyataan yang diberikan oleh ketua kelompok tani organik Margamulya, mereka belum bisa mendapatkan harga sesuai dengan kualitas organik karena konsumen belum mengetahui tentang produk kopi organik. Maka saat ini pengurus masih berusaha untuk mengedukasi konsumen tentang keberadaan serta manfaat dari kopi organik. Diharapkan dengan teredukasinya masyarakat sebagai konsumen dapat membeli produk kopi organik sesuai dengan harga yang diharapkan karena di balik produk organik yang dihasilkan ada usaha yang besar untuk menjaga kualitas sesuai dengan ketentuan organik yang berlaku.

Hasil penelitian ini didukung oleh penelitian H.A.N Van Der Vossen (2005), yaitu premi yang diterima oleh petani organik jelas tidak cukup mengimbangi hasil panen yang lebih rendah, biaya produksi yang sedikit lebih tinggi, dan biaya sertifikasi dan inspeksi yang telah terakreditasi oleh organisasi IFOAM atau lembaga sertifikasi organik. Pendapatan bersih untuk kebun kopi organik dengan demikian $25-50 \%$ lebih rendah daripada petani konvensional, tetapi masih cukup menguntungkan ketika harga kopi tinggi. Pirnsip-prinsip pertanian organik mungkin belum meningkatkan hasil secara substansial dan premi sederhana belum cukup mengkompensasi upaya tambahan yang diperlukan untuk memenuhi peraturan ketat untuk kopi bersertifikat organik.

Meskipun saat ini kelompok tani kopi organik Margamulya belum mengeluarkan biaya untuk sertifikasi karena kelompok tani kopi organik Margamulya mendapatkan sertifikasi tersebut dari program 1.000 desa pertanian organik oleh pemerintah yang disalurkan melalui Dinas Perkebunan Jawa Barat sehingga biaya sertifikasi ditanggung oleh pemerintah. Tidak hanya bantuan sertifikasi, pemerintah memberikan dukungan langsung berupa pelatihan kopi organik kepada kelompok tani kopi organik Margamulya, dan memberikan bantuan langsung berupa dua ekor kambing betina dan dua puluh delapan kambing jantan serta bangunan berupa kandang ternak, dan rumah kompos untuk mendukung produksi kopi organik oleh petani yang tergabung dalam kelompok tani kopi Margamulya. Selain itu, penyebab harga yang 
didapatkan petani kopi organik masih tergolong rendah karena sertifikat organik yang dimiliki kelompok tani kopi organik Margamulya ini baru diperoleh pada tahun 2019 sehingga belum memberikaan banyak manfaat ekonomi.

\section{KESIMPULAN DAN SARAN}

Biaya pengeluaran petani kopi organik lebih tinggi daripada kopi konvensional, sedangkan penerimaan petani kopi konvensional lebih tinggi daripada petani kopi organik sehingga pendapatan kopi konvensional lebih tinggi daripada pendapatan petani kopi organik hal ini disebabkan karena penerapan sistem budidaya organik masih relatif baru diterapkan, petani kopi organik masih mengalami masa konversi lahan dari konvensional menjadi organik.

Adapun beberapa saran yang diberikan adalah untuk petani kopi organik disarankan untuk memastikan produksi kopi organik berkualitas tinggi dengan melakukan teknik produksi sesuai standar pertanian kopi organik yang telah ditetapkan oleh lembaga sertifikasi. Hama dan penyakit serta gulma dapat dikendalikan melalui sejumlah metode yang sesuai dengan standar sistem budidaya organik. Diharapkan dengan diterapkannya budidaya organik sesuai standar akan meningkatkan produktivitas organik serta menghasilkan produk organik yang berkualitas. Produk organik yang berkualitas diharapkan dapat diterima oleh pasar dengan harga premium yang akan diterima oleh petani sehingga pada akhirnya memberikan kesejahteraan terhadap petani kopi organik.

Bagi pemerintah khususnya dinas perkebunan dapat memberikan fasilitas untuk melakukan kontrak atau perjanjian jual beli untuk memastikan produk organik yang dihasilkan petani dapat diterima oleh pasar dengan harga premium. Selain itu, pemerintah disarankan untuk meningkatkan dan memperluas edukasi ke masyarakat mengenai produk kopi organik Indonesia dilakukan dengan mengadakan pameran produk organik Indonesia di dalam atau luar negeri yang dilakukan oleh pemerintah bersama dengan pengurus kolompok tani kopi organik. Selain itu, pemerintah dapat melakukan promosi secara langsung atau media internet dengan tujuan mengedukasi dan mempromosikan kepada masyarakat mengenai keberadaan kopi organik, diharapkan masyarakat dapat menghargai usaha petani organik dengan memberikan 
harga premium pada produk kopi organik.

\section{DAFTAR PUSTAKA}

BPS Perkebunan, S. D. (2017). Statistik Kopi Indonesia. Badan Pusat Statistik Indonesia.

H.A.M Van Der Vossen (2005) A Critical Analysis of The Agronomic and Economic Sustainability of Organic Coffee Production. Expl Agric, volume 41 Camridge Universiry Press

Karyani, T., Karl Andika Mahaputra, Endah Djuwendah, Kuswarini Kusno. (2020). Dampak Pola Tanam Kopi Terhadap Pendapatan Petani (Suatu Kasus di Desa Pulosari, Kecamatan Pangalengan, Bandung). Jurnal Pemikiran Masyarakat Ilmiah Berwawasan Argibsinis, 6(1): 101-112.

Meri Fatmalasari, F. E. (2016). Analisis Manfaat Sertifikasi Indonesian Organic Farm Certification (INOFICE) Terhadap Keberlanjutan Usahatani Kopi Organik di Kecamatan Air Hitam Kabupaten Lampung Barat. Jurnal Ilmu-Ilmu Agribisnis, 4(1): 30-39.

Mayrowani. (2012). Pengembangan Pertanian Organik di Indonesia. Forum Penelitian Agroekonomi.
BPS. (2016). Statistik Perkebunan Indonesia 2015 - 2017. Sekretariat, Direktorat Jenderal Perkebunan, Kementerian Pertanian, Badan Pusat Statistik.

Priyanto, Dwi. (2008). Mandiri belajar SPSS untuk Analisis Data dan Uji Statistik. Yogyakarta. Mediakom

Soekartawi. (1995). Analisis Usahatani . Jakarta: UI Press.

Soekartawi. (2006) Analisis Usahatani. Jakarta. UI Press.

Sugiyono. (2018). Metode Penelitian Kuantitatif. Bandung: Penerbit Alfabeta.

Suratiyah, K. (2015). Ilmu Usahatani. Jakarta: Penebar Swadaya.

Tuti Karyani, Endah Djuwendah, Agriani Hermita Sadeli, Sesilia Kirana, Nurul Risti Mutiasari. (2018). Arabica Coffee Agroindustry Cost Requirement Margamulya Coffee Producers Cooperative. Asian Journal of Agricultural Research, 12(1): 1-9.

Veek Voora, Steffany Bermudez, Cristina Larrea (2019). Global Market Report: Coffee. The International Institure for Sustaianable Development. 